\title{
READERS
nsight
}

Journal of Economic Info (JEI)

ISSN:2313-335X

www.readersinsight.net/jei

\section{Value relevance of accounting information and its impact on stock prices: Case study of listed banks at Karachi Stock Exchange}

\author{
Khurram Shehzad $^{1 *}$, Aisha Ismail ${ }^{2}$ \\ 1,2 Department of Management Sciences, COMSATS Institute of Information Technology, Abbottabad, Pakistan \\ * Corresponding author: kshehzad@ciit.net.pk
}

\begin{abstract}
This study primary investigates the value relevance of accounting information in banking sector of Pakistan. The study employed the pooled regression technique on nineteen private banks from the period of 2008 to 2012. The findings show that earning per share is more value relevant than book values, while accounting data explains a high proportion of the stock price. The relevant information is such that it influences the economic decisions of users by helping them evaluate past, present and future events.
\end{abstract}

\section{ARTICLE INFORMATION}

\author{
Received: 16 May 2014 \\ Revised: 13 July 2014 \\ Accepted: 25 July 2014
}

DOI 10.31580/jei.1i3.109

\section{Introduction}

Value relevance is defined as "the ability of accounting numbers to summarize the information underlying the stock prices, thus the value relevance is indicated by a statistical association between financial information and prices or returns"'( Liu \& Liu 2007 p.56). The value relevance literature deals with the usefulness of financial statement information in equity valuation, i.e., how well do accounting figures measure value? What accounting figures can be used to predict value attributes? These research questions are addressed in this study.

A key role of financial statements is to summaries business transactions and other events. Under this construct, the value relevance of financial statement information is measured by its ability to capture or summarize information, regardless of source, that affects equity value (Francis and Schipper, 1999).

Stock market is a place which facilitates corporations to raise equity capital, facilitates continuous economic growth and maintain liquidity for the holder of the stocks who invest in these stocks for the purpose of capital gain. On the other hand the main objective of accounting data is to provide information about the company's economy to different users inside and outside the company (Smith, 2006).

In this research, the market price per share of the companies is taken as dependent variable and accounting information as independent variable .Accounting information is explained by the earning per share and book value per share.

Stock's price is the most obvious and important criteria for determining the firm's value. So, stocks price maximization is the most important goal for most corporations to maintain their economic growth and credibility in the mind of investors. To answer the question, what determines stock prices? The answer would be that it depends upon the company's ability to generate cash flow now and have a potential to generate in the future. Investors during the investment process compare the value of company which is determined by the prices of the stock (Brigham and Ehrdart, 2001).
Investors to understand the factors affecting to companies stock price anticipated the trend of price changes and company value changes and accordingly make necessary decisions to buy or not to take stock. In this study, company's share has been used as multiplying ending share value in the number of outstanding shares. Financial decisions of any corporations is dependent upon accounting information produced by the accounting system, then on the basis of information available the finance managers are able to make decisions about company's future. The investors' decisions to buy or not to take stock also depend upon this accounting information.

The more investors use accounting information, it is expected that rational decisions are made. But the use of accounting information depends on several factors, some of which are related to users of the information and some others related to the quality and quantity of the information. Financial information is essential in making sound investment decisions and it will reduce the informational asymmetry problem between the firm's managers and the investors (Hossain, et al. 2004).

Accounting information is hypothesized to be value if it conveys information that modifies investor expectations of the firms' future cash flows, and ultimately causes the stock price to change (Scott, 2003). Though the investors use non financial information in order to make investment decisions, still conventional investors give more weight to financial information. A main purpose of accounting is to provide investors with relevant information for their investment decisions (see, e.g., Redovisningsrådet, 1995). According to the survey done by the Boston College (2007), 62\% of respondents favored financial information and only $38 \%$ favor to the non financial information for use in investment decisions.

The main objective of the research is to study the relevance of financial statement information for the valuation of stock. The purpose of this study is to investigate the importance of accounting information for stock market responsiveness. It means whether accounting data provide value-relevant information to investors and other users which are reflected in share price or not

This study is organized as follows i.e., after introduction, section 2 presented the review of literature. Data source and methodological 
framework explained in Section 3. Results discussed in Section 4. Final section concludes the study.

\section{Literature review}

The ample research is available on the said topic; however, this study has an incentive to estimate the value relevance of accounting information with respect to stock price, which are mostly ignored area in the financial research. Abiodun (2012) conducted a research on the value relevance in corporate sectors' of Nigeria and used logarithmic regression models on 40 companies for the period between 1999 to 2009. The results conclude that earnings is more value relevant than book values by extension that, the information contained in the income statements, dictates more the corporate values of firms in Nigeria than the information contained in the balance sheet. Relevant information is such that it influences the economic decisions of users by helping them evaluate past, present and future events.

Abayadeera (2010) tested for the value relevance of financial and non-financial information in high-tech industries in Australia with a sample size of 91 companies running through various sectors of the Australian economy. The Ohlson's (1995) Equity Valuation Model (modified for the intangible assets disclosure) was explicitly applied to examine the value relevance of financial and non-financial information with an overall results that provided evidence that book value is the most significant factor and earnings are the least significant factor in deciding share prices in high-tech industries in Australia. This finding of Abayadeera (2010) further supported previous studies that showed value relevance declined in earnings but increase in book value.

Glezakos, et al. (2012) studied the impact of earnings and book value in the formulation of stock prices on a sample of 38 companies listed in the Athens Stock Market during the 1996-2008 period. The results concluded that the joint explanatory power of the above parameters in the formation of stock prices increases over time. The study further examined that the impact of earnings is diminishing, compared to the book value, while investors strive towards analyzing the fundamental parameters of businesses. Mohammadi, et al. (2012) investigates the relationship between accounting information and the value of the companies accepted in Tehran exchange market. The profit quality characteristic index is to be related and to be on-time. The number of 194 companies was selected by systematic method as the statistics sample in the period of 2007-2009. The results found that that there is no relationship between accounting information and companies' value (stock value), The study argue that this may be happened due to lack of efficiency of investment market and inability in using the accounting information by investment market activists.

Halonen, et al. (2013) conducted a research in order to measure the value relevance between accounting data and stock prices from OMX (Sweden) Large Cap between 2007-2010. The results revealed that value relevance from the balance sheet, measured by BVPS, has increased as compared to EPS. The results also show that accounting data explains a high proportion of the stock price. Perera (2010) addressed the relevance of Accounting Information on investor's stock market decisions in Commercial Banks registered under Colombo Stock Exchange (CSE) in Sri Lanka. The relevance of accounting data was measured by correlation coefficient between Market Price per Share (MPS) and selected accounting information such as Earning per Share (EPS), Return on Equity (ROE) and Earning Yield (EY). The data analysis was based on the AI in the published financial statements of Commercial banks registered under CSE for a period of 5 years from 2006 to 2009. The study concluded that there is a relationship between Accounting Information and Market Price per Share. Further, the study examined that investors still consider Accounting Information which contain in the published financial statements of Commercial Banks registered under CSE for the stock market decisions in Sri Lanka.

Nayeri (2012) examined the factors affecting the value relevance of accounting information for investors in the Tehran Stock Exchange over the period of six years. In the study, the effect of four factors; being profitable or loss generating, company size, earnings stability and company growth on the value relevance of accounting information have been studied. For this purpose Ohlson model and the cumulative regression analysis was used in order to examine the hypotheses and as the basis of data analysis T-test by Regression coefficient analysis is deployed. The study concluded that that these factors influence on the value relevance of accounting information for investors in Tehran Stock Exchange.

Klimczak, (2010) extending comparative value relevance research by examining patterns in the value relevance of accounting numbers as a function of the month in which he observed current market values. The study estimated the model on a sample of stock-exchange listed companies from Germany and France and find dramatically divergent patterns of fit. In France, The study concluded that accounting numbers have strong relevance for market valuation after publication of annual reports in February or March. How ever in Germany, accounting numbers have stronger relevance during the fiscal year.

Hadi (2004) tested the information content of accounting data in Kuwaiti banks to the investors in stock exchange market. Six financial ratios are used in research along with regression analysis to clear the problems of research. The research results indicated that accounting information is very useful to investors in Kuwaiti banks, and most ratios are significant except the loss ratio.

Pervan, (2012) based on the sample of 97 corporations analyzed the value relevance of accounting information on the capital markets of Southeast Europe. In the first part of the research they analyzed and compared value relevance on the following capital markets: Ljubljana Stock Exchange, Zagreb Stock Exchange, Sarajevo Stock Exchange, Banja Luka Stock Exchange and Belgrade Stock Exchange. The research results have shown that the accounting information are value relevant on all the observed markets but also that there are certain differences in the value relevance among countries. In the second part of the research they tested the hypothesis that level of transparency is positively related with value relevance i.e. higher transparency of annual report should result with higher value relevance of accounting information.

Akarim, etal. (2012) examined the relationship between accounting earnings and stock market returns by using Panel Granger Causality test in Turkish Banking Sector. The study used data for banks which are traded in Istanbul Stock Exchange from the period between 20002010. The findings reveal that there is two way relationship between stock returns and accounting earnings supporting the relevance theory. Investors get abnormal returns in Turkish banking sector by using accounting earnings.

Mgbame (2013) conducted a study to ascertain if accounting information contributes to stock volatility in the Nigerian Capital Market. The study investigated the effect of accounting information on the volatility of stock market returns in Nigeria using GARCH models. The results from models showed that accounting information explains and accounts for stock volatility in the Nigerian stock market. Specifically, information on book values, earnings per share and dividend per share is found to be related to stock volatility. Miah (2012) assess the extent of association between two influential accounting variables (EPS and NAVPS) and market price of share. The study found that there is poor relationship between these two as only about $6.5 \%$ of changes in share price can be explained by changes in defined accounting variables. There is also a negative correlation between NAVPS and Share Price. Rather, it was found that a number of other qualitative factors also affect the market price such as information from speculators or other co investors.

The above studies show the strong correlation between value relevance of accounting information and stock prices. The subsequent section analyzes the relationship between value relevance and stock prices in the banking section or Pakistan.

\section{Data source and methodological framework}

Our sample consists of nineteen Private sector banks listed on Karachi stock exchange. The secondary data is taken from the official site of the State bank of Pakistan and Karachi Stock Exchange. 
Annual data of during the period 2008-2012 have been collected from the above mentioned sites i.e.,

Total number of Banks

48

Total Private Banks (Conventional +Islamic)

Private Banks listed at Karachi stock exchange

Banks included in the sample

Final sample size

Table 1 shows the list of private sectors bank in Pakistan.

Table 1: List of Private Sector Banks

\begin{tabular}{ll}
\hline S.No & Name of the Bank \\
\hline 1 & Bank Alfalah Itd \\
2 & Bank Al Habib Itd \\
3 & Allied Bank limited \\
4 & Askari Bank limited \\
5 & Bank Islami limited \\
6 & Faysal Bank Limited \\
7 & Habib Bank limited \\
8 & Habib Metropolitan bank limited \\
9 & JS Bank limited \\
10 & KASB Bank limited \\
11 & MCB Bank limited \\
12 & Meezan Bank limited \\
13 & NIB Bank Limited \\
14 & Samba Bank limited \\
15 & Silk Bank Limited \\
16 & Soneri Bank limited \\
17 & Standard Chartered Bank limited \\
18 & Summit Bank limited \\
19 & United Bank limited \\
\hline
\end{tabular}

This study uses a price model to analyze the results, since the share price is the dependent variable where as EPS and BKPS are two independent variables. This study is based on the secondary sources of information. Mainly this study examine the empirical relationship between accounting information or variables like Earning per Share (EPS), BVPS, and equity share price in the market for the period of 2008-2012 in KSE database.

The research hypotheses are as follows i.e.,

H1: The earning per share significantly affects the stock price.

H2: The Book value per share significantly affects the stock price.

\section{Results}

Table 2 shows the descriptive statistics of the variable.

Table 2: Descriptive Statistics

\begin{tabular}{llll}
\hline & MPPS & EPS & BVPS \\
\hline Mean & 30.38011 & 3.836316 & 25.28128 \\
Maximum & 228.5400 & 24.47000 & 98.523 \\
Minimum & 1.100000 & -4.540000 & 0.218707 \\
Std. Dev. & 46.57917 & 6.778852 & 26.365 \\
Skewness & 2.612507 & 1.596638 & 1.642 \\
Kurtosis & 9.916675 & 4.784390 & 4.512 \\
Observations & 95 & 95 & 95 \\
\hline
\end{tabular}

The mean value of MPPS is 30.38 . While the mean value of EPS and BVPS is 3.84 and 25.28. Table 3 shows the correlation matrix.

Table 3: Correlation Matrix

\begin{tabular}{llll}
\hline & MPPS & EPS & BVPS \\
\hline MPPS & 1 & & \\
EPS & 0.928 & 1 & 1 \\
BVPS & -0.030 & -0.01 & 1 \\
\hline
\end{tabular}

The results showed the existence of high positive correlation between EPS and MPPS. While the correlation between BVPS and MPPS is quite low and negative. Table 4 shows the panel least square regression estimates.

The study highlighted the significant role of EPS and BVPS in determining the levels of MPPS. The results are satisfactory in terms of usual diagnostic tests. The value of $\mathrm{R}^{2}$ is quite high depicting that about $86.1 \%$ of the total variation in dependent variable is explained by independent variables. There is no problem of autocorrelation in the model as shown by the value of D.W stats. The overall performance of the model is satisfactory as shown by F-statistics.

Table 4: Panel Least Square Regression

\begin{tabular}{|c|c|c|c|c|}
\hline \multicolumn{5}{|c|}{ Dependent Variable: MPPS } \\
\hline \multicolumn{5}{|c|}{ Method: Pooled Least Squares } \\
\hline Variable & Coefficient & Std. Error & t-Statistic & Prob. \\
\hline $\mathrm{C}$ & 6.028143 & 2.081372 & 2.896236 & 0.0047 \\
\hline EPS & 6.372850 & 0.267102 & 23.85923 & 0.0000 \\
\hline BVPS & -4.121522 & 0.972858 & -41.518410 & 0.0000 \\
\hline R-squared & 0.860998 & \multicolumn{2}{|c|}{ Mean dependent var } & 30.38011 \\
\hline $\begin{array}{l}\text { Adjusted R- } \\
\text { squared }\end{array}$ & 0.857976 & \multicolumn{2}{|c|}{ S.D. dependent var } & 46.57917 \\
\hline $\begin{array}{l}\text { S.E. of } \\
\text { regression }\end{array}$ & 17.55386 & \multicolumn{2}{|c|}{ Akaike info criterion } & 8.599495 \\
\hline $\begin{array}{l}\text { Sum squared } \\
\text { resid }\end{array}$ & 28348.70 & \multicolumn{2}{|c|}{ Schwarz criterion } & 8.680143 \\
\hline Log likelihood & -405.4760 & \multirow{2}{*}{\multicolumn{2}{|c|}{$\begin{array}{l}\text { F-statistic } \\
\text { Prob(F-statistic) }\end{array}$}} & 284.9299 \\
\hline Durbin-Watson & 1.732970 & Prob(F-statistic) & & 0.000000 \\
\hline
\end{tabular}
stat

From the above statistical data it is obviously apparent that there is a relationship between the changes in share price and changes in accounting variables (i.e. EPS and BVPS). Because sample Banks show that there is only $92.8 \%$ relationship between changes in EPS and changes in share price of those banks and weak negative relationship between changes in BVPS and changes in share price.

Now if we see the hypothesis testing, it can be concluded that predefined null hypothesis is rejected as there is a strong relationship between the earning per share and book value per share. On the other hand there is a negative relationship between changes in share price and Book value per share. So, second null hypothesis is accepted. Hence it is apparently assumed that accounting information is properly reflected on share price or investors use the accounting information to make their investment decision in Pakistan and share price is significantly influenced by the changes in accounting variables. Rather other qualitative factors also play an important role in this aspect. It may be for example, appointment or dismissal of key personnel in the regulatory authority like Security Exchange Commission (SEC), changes in major policies of the organization affecting investors economic well being, declaration of dividend, changes of chief staff in commerce ministry, or Finance Ministry, Law and order situation and political conditions etc.

\section{Conclusion}

The present study has been undertaken to assess the extent of association between two accounting variables (i.e., EPS and BVPS) and market price of share. It is found there is strong relationship between these two. There is also a negative correlation between BVPS and Share Price. From this study, it is suggested that investors should have basic knowledge of business and economics. They should be well informed when making their investment decision. They should not depend on the information from speculators or other co investors who have the similar interest on the identical phenomenon. Rather they should go through the audited annual reports which provide the mirror of the company's performance, financial position and changes in control of the owners.

\section{References}

Abiodun, B. Y. (2012). Significance of Accounting Information on Corporate Values, 1(2), 105-113.

Akarim, Y. D., Celik, S., \& Zeytinoglu, E. (2012). The Causality Relationship between Accounting Earnings and Stock Returns in the Light of Value Relevance Theory.

Ben, S., \& Nachi, W. (n.d.). Does the Tunisian accounting reform improve the value relevance of financial information? Does the Tunisian accounting reform improve the value relevance of financial information ?, 1-27.

Brigham, E., \& Ehrhardt, M. (2001). Financial management: theory \& practice. Cengage Learning. 
Francis, J., \& Schipper, K. (1999). Have financial statements lost their relevance?. Journal of accounting Research, 319-352.

Glezakos, M., Mylonakis, J., \& Kafouros, C. (2012). The Impact of Accounting Information on Stock Prices: Evidence from the Athens Stock Exchange. International Journal of Economics and Finance, 4(2), 56-68. doi:10.5539/ijef.v4n2p56

Gómez-Biscarri, J., \& López-Espinosa, G. Fair Value Accounting and Firm Valuation.

Hadi, M. M. (2004). The Importance of Accounting Information to the Investors in Banking sector: Kuwaiti Evidence By Kuwait University.

Ikhatua, O. J. (2013). Accounting Information and Stock Volatility in the Nigerian Capital Market: A Garch Analysis Approach. International Review of Management and Business Research, 2(1), 265-281.

Liu, J., \& Liu, C. (2007). Value relevance of accounting information in different stock market segments: the case of Chinese A-, B-, and H-shares. Journal of international accounting research, 6(2), 55-81.
Mohammadi, A. (2012). The Investigation of Relationship between Accounting Information and the Value of Companies (Case Study), http://www.icndbm.com/pdf/129.pdf

Naceur, B., \& Nachi, W. (2007). 'Does the Tunisian Accounting Reform Improve the Value Relevance of Financial Information? Online available at:

http://www.adoptifrs.org/uploads/Tunisia/Does\%20the\%20Tunisian\%20a ccounting\%20reform\%20improve $\% 20$ the $\% 20$ value $\% 20$ releva.pdf

Nayeri, M. D., Ghayoumi, A. F., \& Bidari, M. A. (2012). Factors Affecting the Value Relevance of Accounting Information. International Journal of Academic Research in Accounting, Finance and Management Sciences, 2(2), 76-84.

Pervan, I., \& Bartulović, M. (2013). Impact of transparency level on the value relevance of accounting information: empirical analysis for SEE countries. izlazi u samo elektroničkom izdanju: NE.

Stergios, A., Athanasios, V., \& Nikolaos, D. (2005). Financial statement effects of adopting international accounting standards: the case of Greece. Journal Of Accounting Research. 